\title{
A Preliminary Temporal Analysis of the East Texas Archaic
}

Robert Z. Selden Jr.

Heritage Research Center, Stephen F. Austin State University

Follow this and additional works at: https://scholarworks.sfasu.edu/ita

Part of the American Material Culture Commons, Archaeological Anthropology Commons, Environmental Studies Commons, Other American Studies Commons, Other Arts and Humanities Commons, Other History of Art, Architecture, and Archaeology Commons, and the United States History Commons

Tell us how this article helped you.

This Article is brought to you for free and open access by the Center for Regional Heritage Research at SFA ScholarWorks. It has been accepted for inclusion in Index of Texas Archaeology: Open Access Gray Literature from the Lone Star State by an authorized editor of SFA ScholarWorks. For more information, please contact cdsscholarworks@sfasu.edu. 


\section{A Preliminary Temporal Analysis of the East Texas Archaic}

Creative Commons License

(c) (i) (8)

This work is licensed under a Creative Commons Attribution-NonCommercial 4.0 International License 


\title{
A Preliminary Temporal Analysis of the East Texas Archaic
}

\author{
Robert Z. Selden, Jr.
}

\section{INTRODUCTION}

This article presents preliminary findings of a temporal analysis of the East Texas Archaic based upon the examination of radiocarbon ${ }^{14} \mathrm{C}$ dates from sites that have deposits that date to the period. All assays employed in this effort were collected from research and cultural resource management reports and publications, synthesized, then recalibrated in version 4.1.7 of OxCal (Bronk Ramsey 2013) using IntCal09 (Reimer et al. 2009).

The date combination process is used herein to refine site-specific summed probability distributions, illustrating - for the first time - the temporal position of each dated archaeological site with an assay that falls within the Archaic. Seventy-three radiocarbon dates from 34 sites serve as the foundation for this analysis of the East Texas Archaic period (ca. 8000-500 B.C.) (Table 1). All dates used in this analysis come directly from the East Texas Radiocarbon Database (ETRD) (Perttula and Selden 2011). Within the sample, there are 19 sites with a single radiocarbon sample that dates to the Archaic, eight sites with two dated samples, one site with three dated samples, three sites with four dated samples, one site with five dated samples, and one site with 14 dated samples (Table 1). Of the $73{ }^{14} \mathrm{C}$ dates from the ETRD used in this analysis, one dates to the Early Archaic period (ca. 8000-5000 B.C.), eight date to the Middle Archaic period (ca. 5000-3000 B.C.), and the remaining 64 date to the Late Archaic period (ca. 3000-500 B.C.) (temporal divisions follow Perttula and Young [2012]).

\section{METHODS}

The date combination (R_Combine) process assumes that if all assays collected at a particular site draw carbon from the same reservoir, then they should have the same underlying $\mathrm{F}^{14} \mathrm{C}$ value and can be combined prior to calibration (Bronk Ramsey 2008). The measurements have Gaussian uncertainty distributions, and $X^{2}$ was used to test the assumption that all ratios are the same to reveal whether compelling evidence exists - at the 95\% confidence level - that dates cannot be related to the same event (Bronk Ramsey 2008). Each site-specific figure provides the summed probability distributions (SPDs), calibrated age range for combined assays, and all dates utilized to determine these results.

Although ${ }^{14} \mathrm{C}$ determinations are most often represented in the form $A \pm E$ where $A$ is the radiocarbon estimate (B.P.) and $E$ represents the standard deviation, the method of date combination can be used to create a new ${ }^{14} \mathrm{C}$ determination from multiple assays, often with the ancillary benefit of a decrease in the standard deviation (Ward and Wilson 1978). To test whether a series of ${ }^{14} \mathrm{C}$ determinations are consistent, the pooled mean is calculated by way of $A p$, where:

$$
A_{p}=\left(\sum_{1}^{n} A_{i} / E_{i}^{2}\right) /\left(\sum_{1}^{n} 1 / E_{i}^{2}\right)
$$




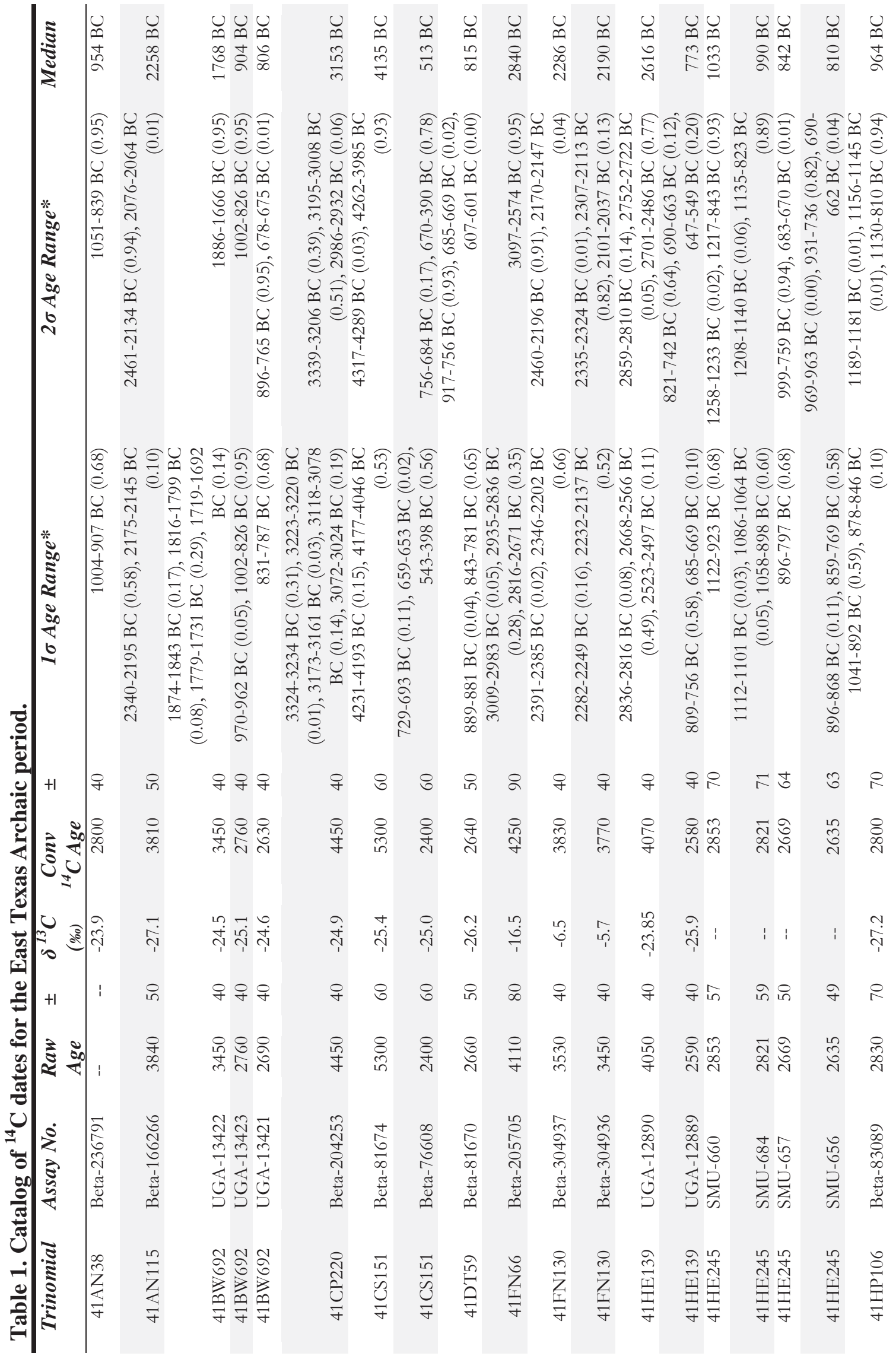




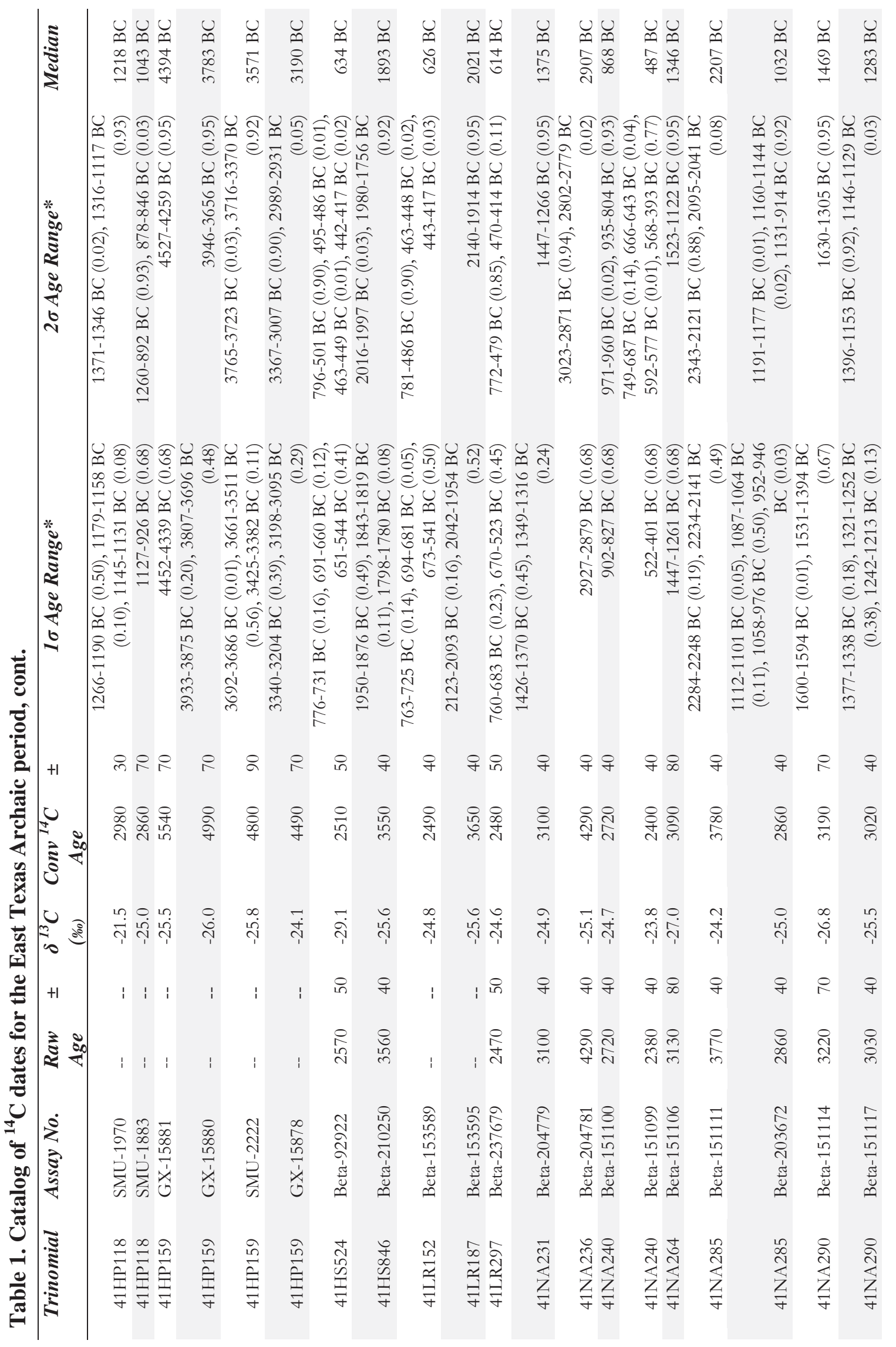




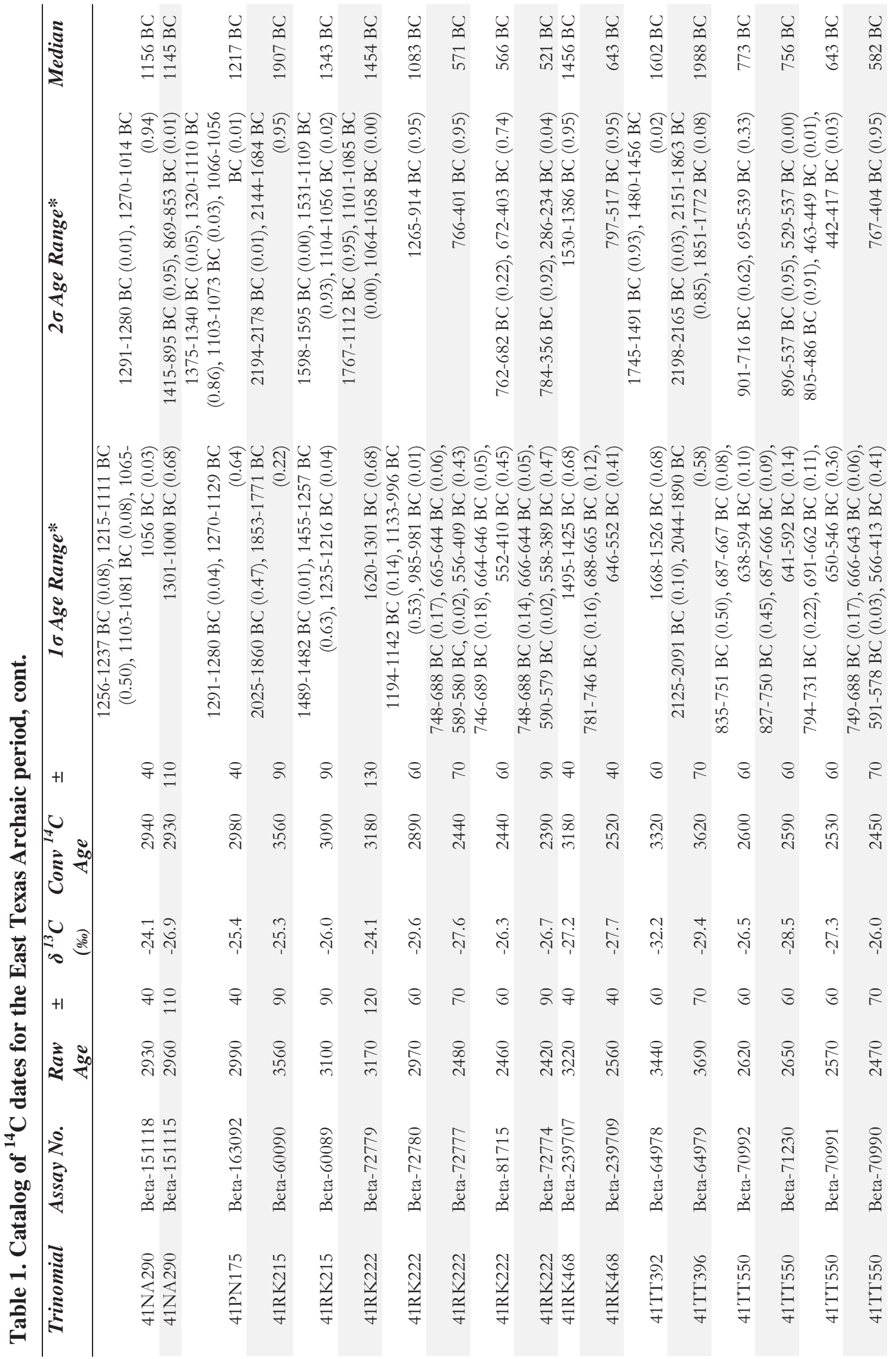




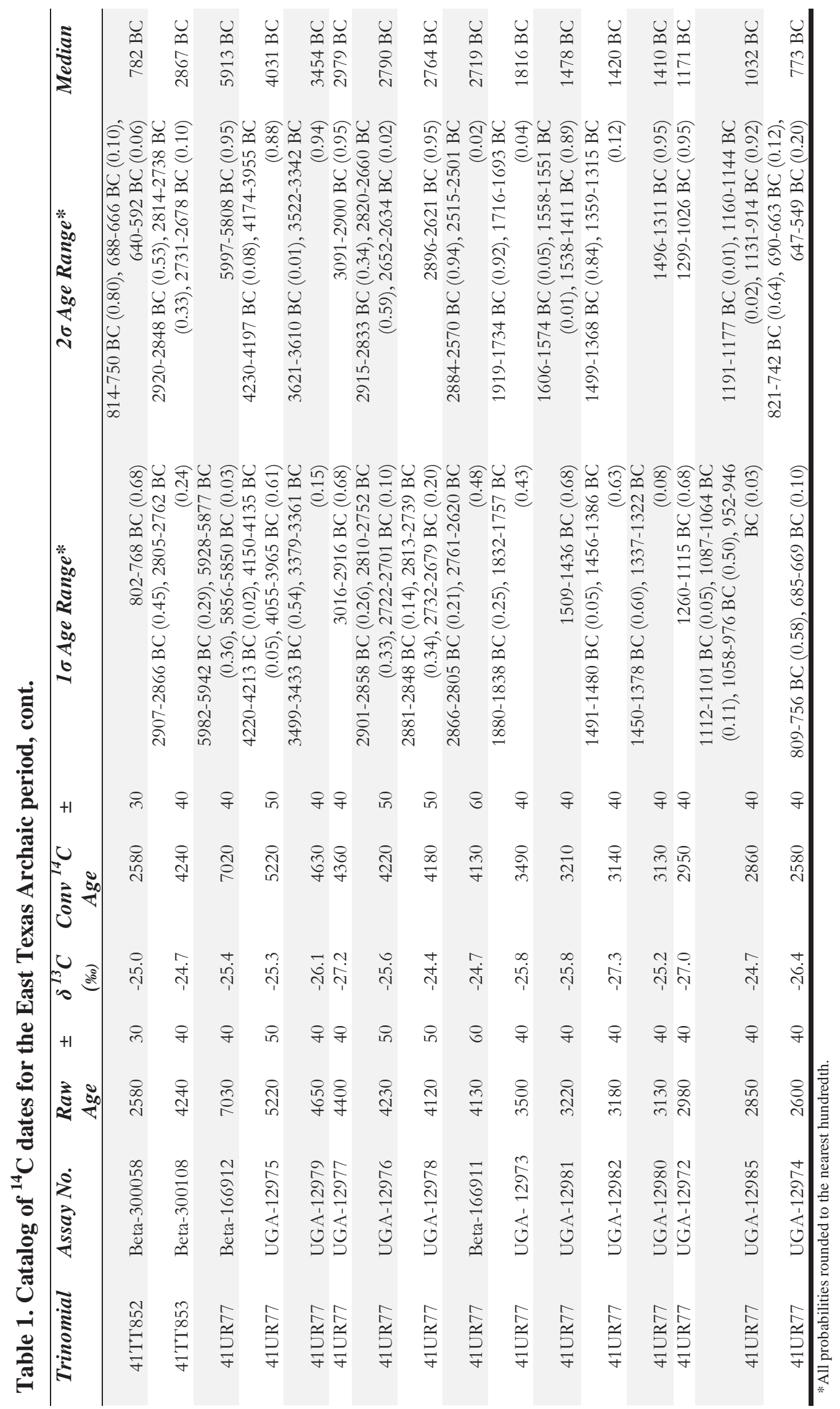


followed by the test statistic, $T$, where:

$$
T=\sum_{1}^{n}\left(A_{i}-A_{p}\right)^{2} / E_{i}^{2}
$$

the latter of which illustrates a chi-square distribution on $n-1$ degrees of freedom under the null hypothesis (see Clark 1975:252; Ward and Wilson 1978:21).

Provided that the ${ }^{14} \mathrm{C}$ determinations are found not to be significantly different, they can then be combined with the pooled age as $A p$ given by (I), and the variance given by:

$$
V\left(A_{p}\right)=\left(\sum_{1}^{n} 1 / E_{i}^{2}\right)^{-1}
$$

(Ward and Wilson 1978:21), which is a process accessible in OxCal by way of the R_Combine function. Once combined with R_Combine, a new date range, standard deviation, and median age is provided for the combined samples (Figure 1). Within the framework of this study, the new date range replaces the combined dates and this new date range is employed within the revised summed probability distribution, while the new median date is used for statistical analyses (see also Selden 2012,2013).

Conventional radiocarbon dates employed were recalibrated using IntCal09 (Figure 2). The radiocarbon curve serves as the basis for date calibration and can aid the process of archaeological interpretation by highlighting temporal zones with reversals and plateaus. Within the span of time of the East Texas Archaic (ca. 8000-500 B.C.), the curve possesses a number of reversals and plateaus that warrant further consideration. These nuances help to clarify why some radiocarbon dates have longer spans of probability than others.

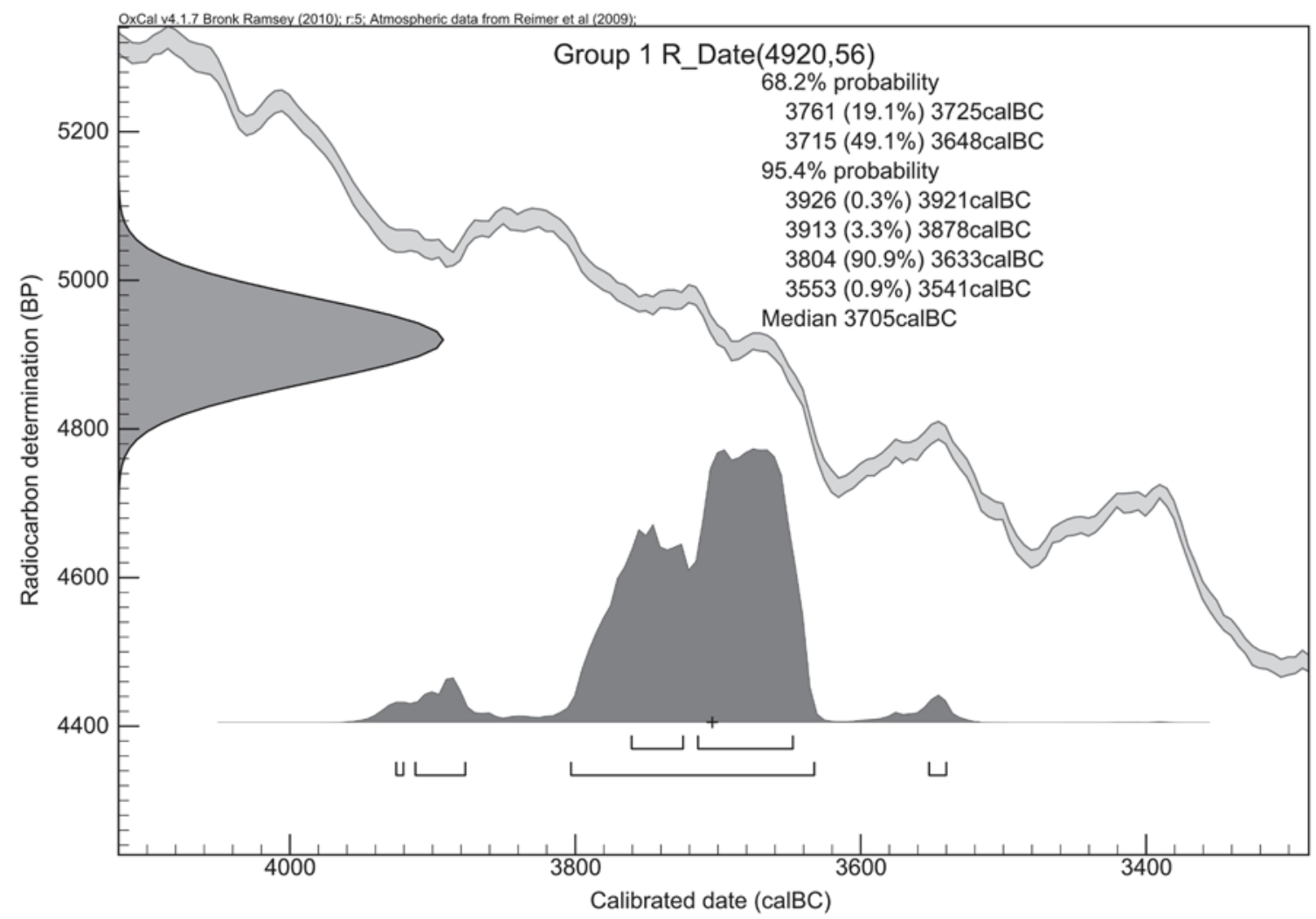

Figure 1. Calibrated results from the R_Combine function for the Finley Fan site (41HP159), Group 1. 


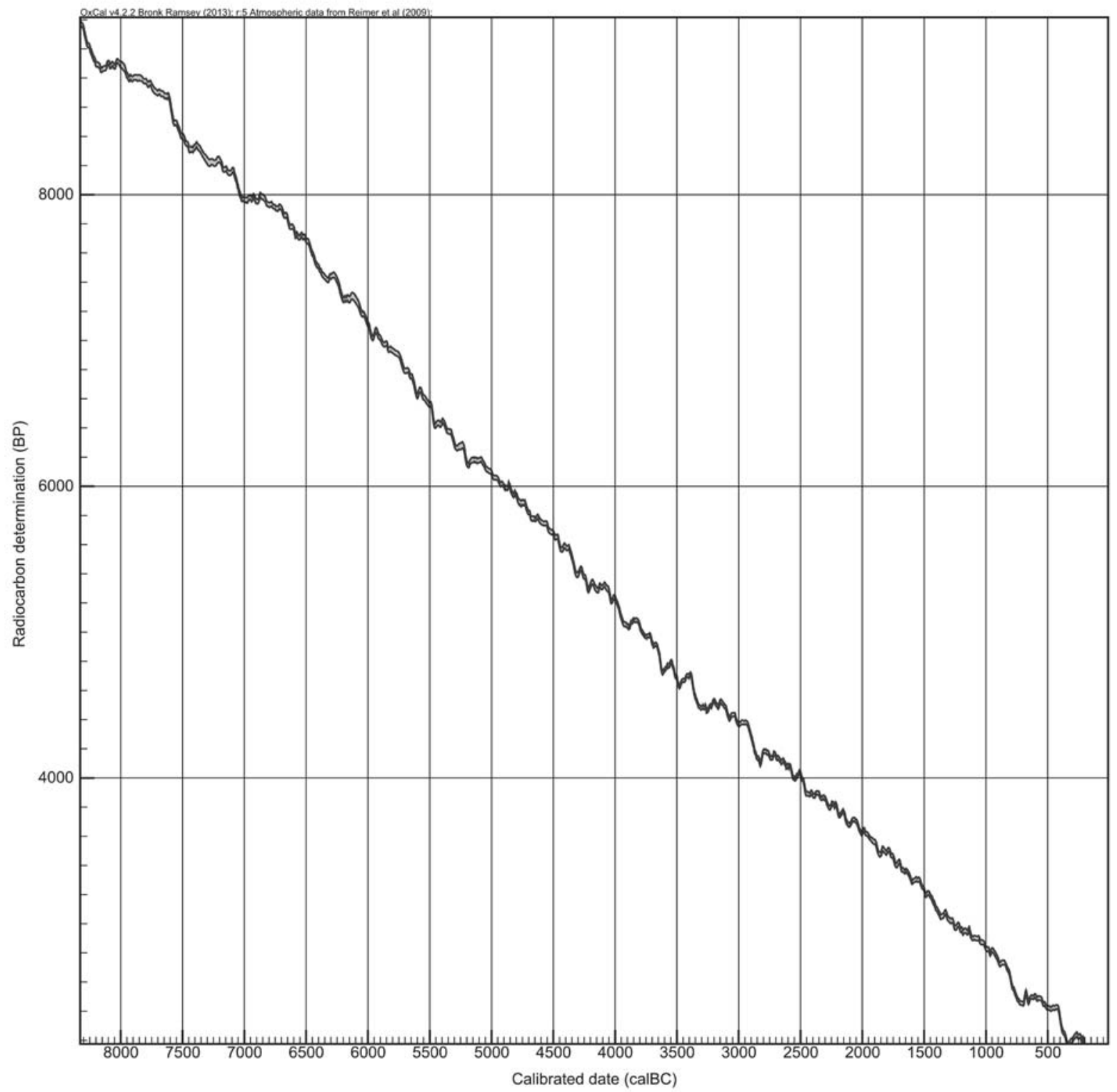

Figure 2. IntCal09 Radiocarbon calibration curve for the Archaic period.

The 1248 corrected dates in the ETRD were calibrated utilizing OxCal 4.1.7 (Bronk Ramsey 2013) and IntCal09 (Reimer et al. 2009). With few exceptions, older assays found to lack $\delta 13 \mathrm{C}$ value estimates for fractionation correction used -25\% for nutshells and charcoal (C3 plants) (Stuiver and Reimer 1993:Table 1).

Upon completion of the date combination process, a summed probability distribution (SPD) was produced for each of the sites with Archaic dates to illustrate the temporal position of each within the period. The dates were plotted in a manner where the SPDs, the combined groups, and the individual assays that inform them can be viewed together. These efforts permit the uncombined SPD for each site to be contrasted with the combined SPD and the combined groups that comprise it. This comparison demonstrates the impact that each site has upon the whole of the Archaic sample, and allows for a discussion of regional trends within the temporal sample. 


\section{COMBINING THE SAMPLE}

Archaic sites with combined ${ }^{14} \mathrm{C}$ dates include: Shell Lens (41FN130), Winston (41HE245), Finley Fan (41HP159), J. Simms (41NA290), Herman Ballew (41RK222), Mockingbird (41TT550), and 41 UR77. The number of dates garnered through research at each of these sites is biased by variable research designs, mitigation strategies, and access to funding. In the following section, the ${ }^{14} \mathrm{C}$ assays from these seven sites are refined through date combination, and the subsequent results (combined dates) replace the original assays within the analysis of all Archaic sites.

\section{Shell Lens (41FN130)}

The Archaic period dates from the Shell Lens site (Beta-304937 and Beta-304936) were combined into one group (Figure 3). The conventional age for Group 1 is $3800 \pm 29$ B.P., which has a calibrated $1 \sigma$ age range of 2287-2201 B.C. (0.68), a $2 \sigma$ age range of 2339-2315 B.C. (0.03) and 2310-2139 B.C. (0.93), with a median age of 2238 B.C.

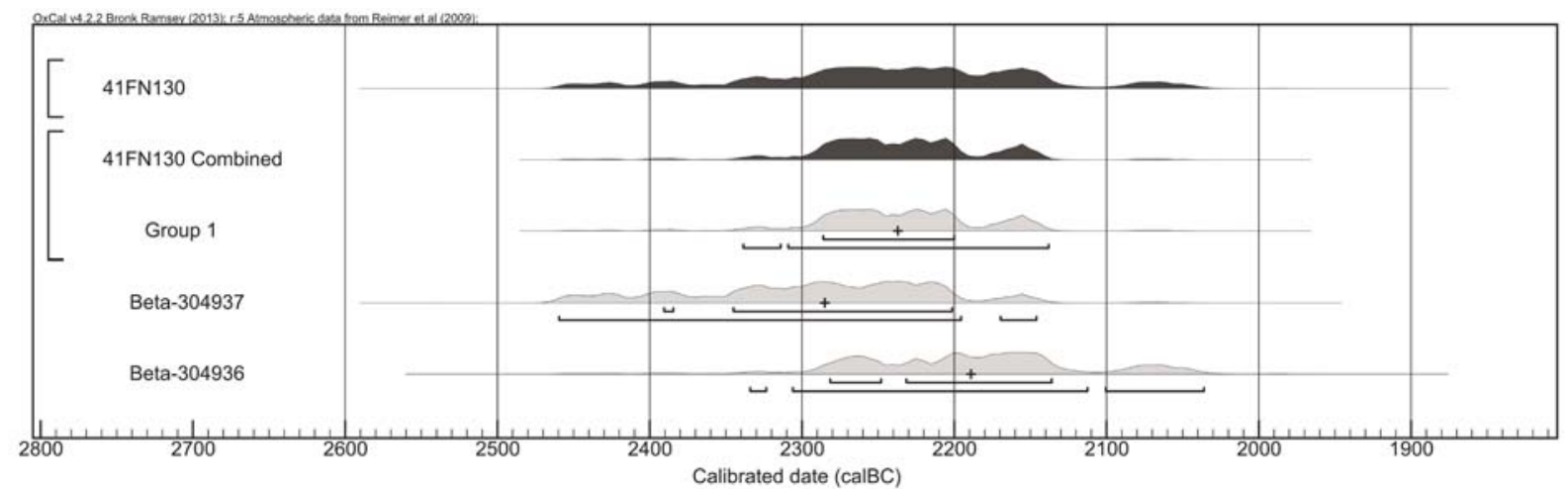

Figure 3. All and combined summed probability distributions for Archaic period dates from the Shell Lens site (41FN130) with $1 \sigma$ and $2 \sigma$ ranges, median ages, and number of samples.

\section{Winston (41HE245)}

The Archaic period dates from the Winston site were combined into two groups (Figure 4). The conventional ${ }^{14} \mathrm{C}$ age for Group 1 (SMU-660 and SMU-684) is $2837 \pm 50$ B.P., which has a calibrated $1 \sigma$ age range of 1056-916 B.C. (0.68), a $2 \sigma$ age range of 1191-1178 B.C. (0.01), 1160-1144 B.C. (0.01), 1131-892

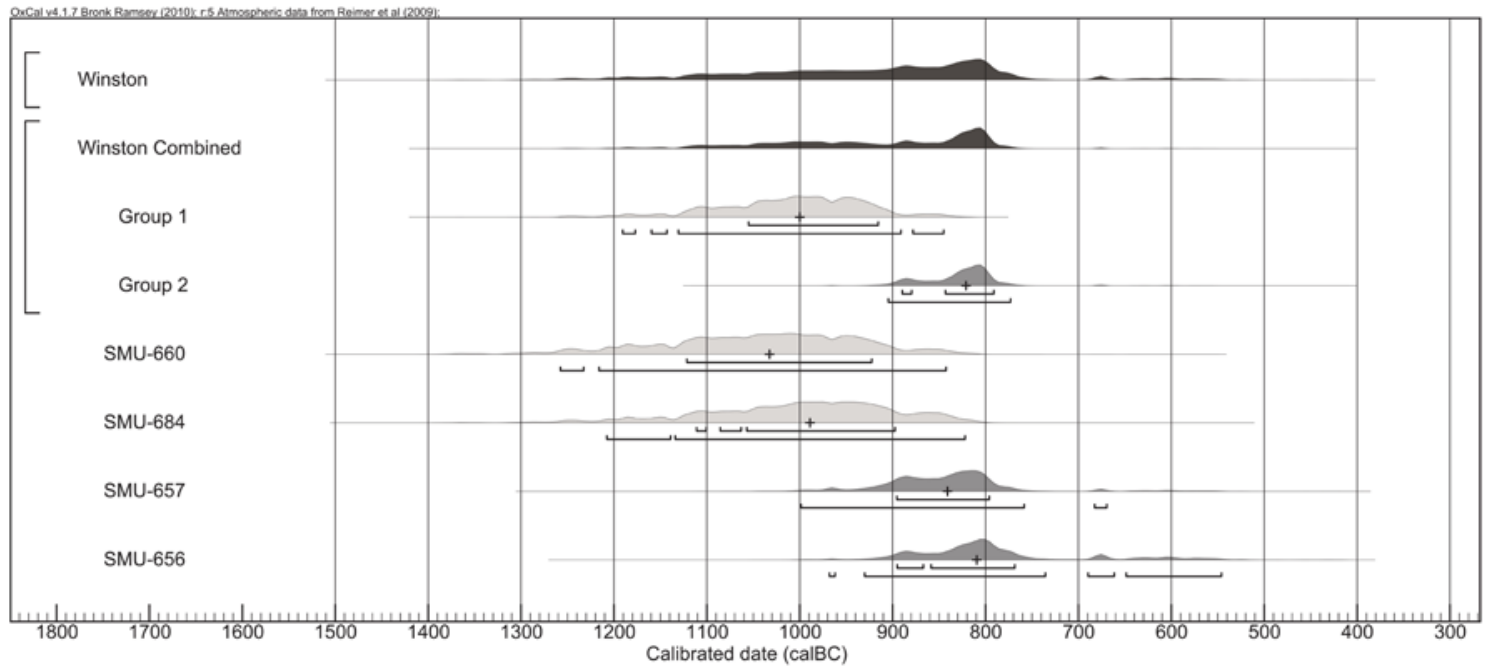

Figure 4. All and combined summed probability distributions for Archaic period dates from the Winston site (41HE245) with $1 \sigma$ and $2 \sigma$ ranges, median ages, and number of samples. 
B.C. (0.91), and 879-846 B.C. (0.03), with a median age of 1001 B.C. The conventional age for Group 2 (SMU-657 and SMU-656) is $2652 \pm 45$ B.P., which has a calibrated $1 \sigma$ age range of 890-880 B.C. (0.06) and 844-792 B.C. (0.63), and a $2 \sigma$ age range of 905-774 B.C. (0.95), with a median age of 822 B.C.

\section{$41 \mathrm{HP118}$}

The Archaic period dates from 41HP118 are represented by one group (SMU-1970 and SMU-1883) (Figure 5). The conventional ${ }^{14} \mathrm{C}$ age for Group 1 is $2962 \pm 28$ B.P., which has a calibrated $1 \sigma$ age range of 1257-1234 B.C. (0.15) and 1217-1130 B.C. (0.54), a $2 \sigma$ age range of 1295-1111 B.C. (0.91), 1103-1074 B.C. (0.03), and 1066-1056 B.C. (0.01), with a median age of 1190 B.C.

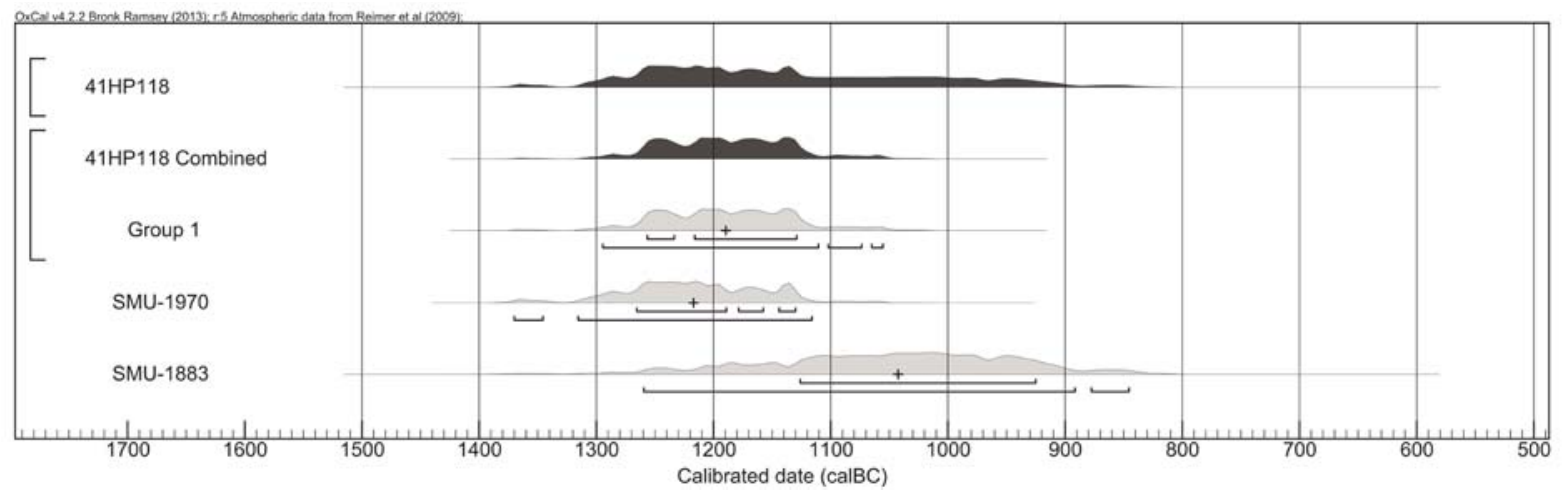

Figure 5. All and combined summed probability distributions for Archaic period dates from 41HP118 with $1 \sigma$ and $2 \sigma$ ranges, median ages, and number of samples.

\section{Finley Fan (41HP159)}

The Archaic period dates from the Finley Fan site are represented by two individual assays (GX-15881 and GX-15878) and one group (GX-15880 and SMU-2222) (Figure 6). The conventional age for Group 1 is $4920 \pm 56$ B.P., which has a calibrated $1 \sigma$ age range of 3761-3725 B.C. (0.19) and 3715-3648 B.C. (0.49), a $2 \sigma$ age range of 3926-3921 B.C. (0.00), 3913-3878 B.C. (0.03), 3804-3633 B.C. (0.91), and 3553-3541 B.C. (0.01), with a median age of 3705 B.C.

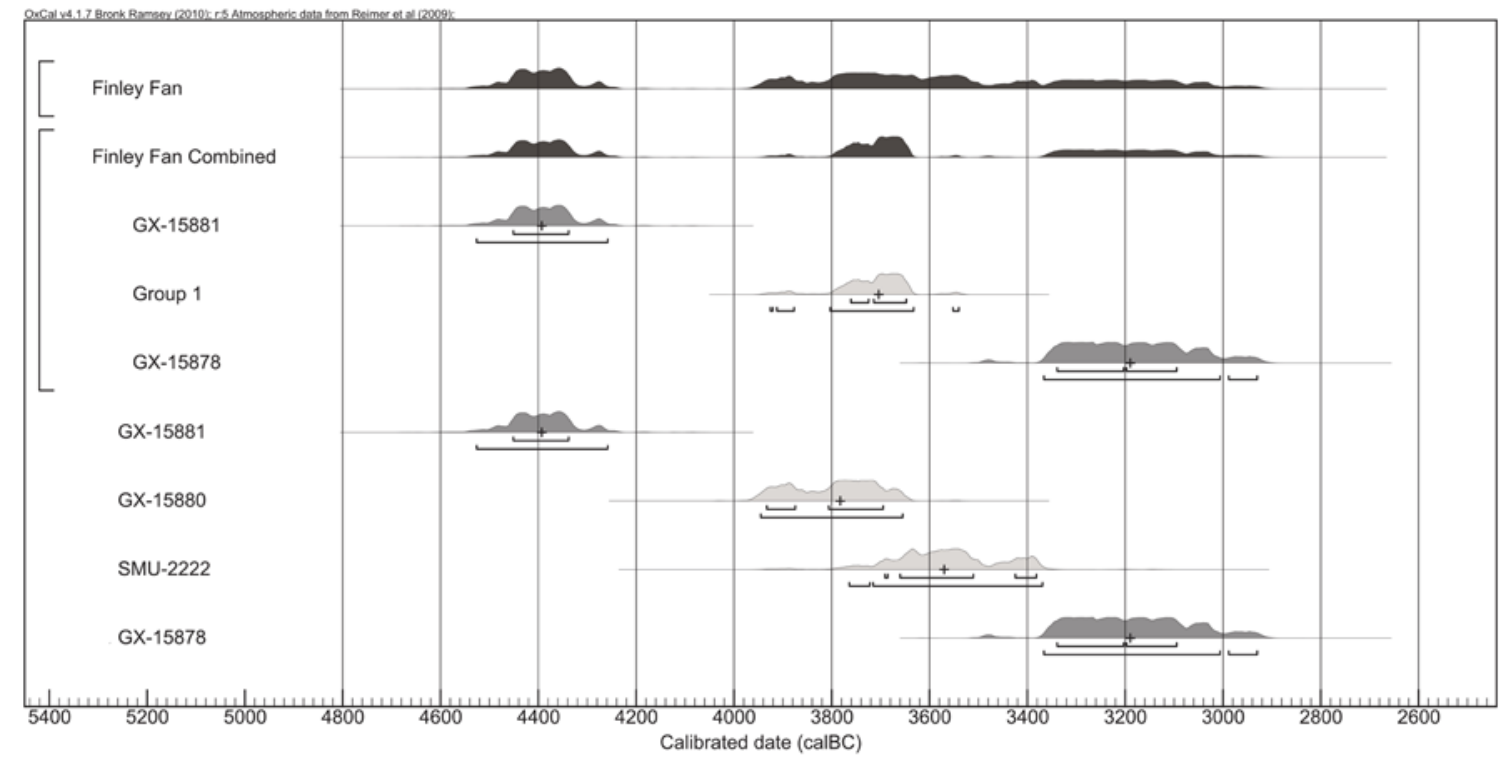

Figure 6. All and combined summed probability distributions for Archaic period dates from the Finley Fan site (41HP159) with $1 \sigma$ and $2 \sigma$ ranges, median ages, and number of samples. 


\section{J.Simms (41NA290)}

The Archaic period dates from the J. Simms site are represented by a single individual assay (Beta151114) and one group (Beta-151117, Beta-151118, and Beta-151115) (Figure 7). The conventional age for Group 1 is $2977 \pm 28$ B.P., which has a calibrated $1 \sigma$ age range of 1264-1191 B.C. (0.50), 1178-1160 B.C. (0.10), and 1144-1131 B.C. (0.08), and a $2 \sigma$ age range of 1368-1361 B.C. (0.01) and 1314-1116 B.C. (0.95), with a median age of 1214 B.C.

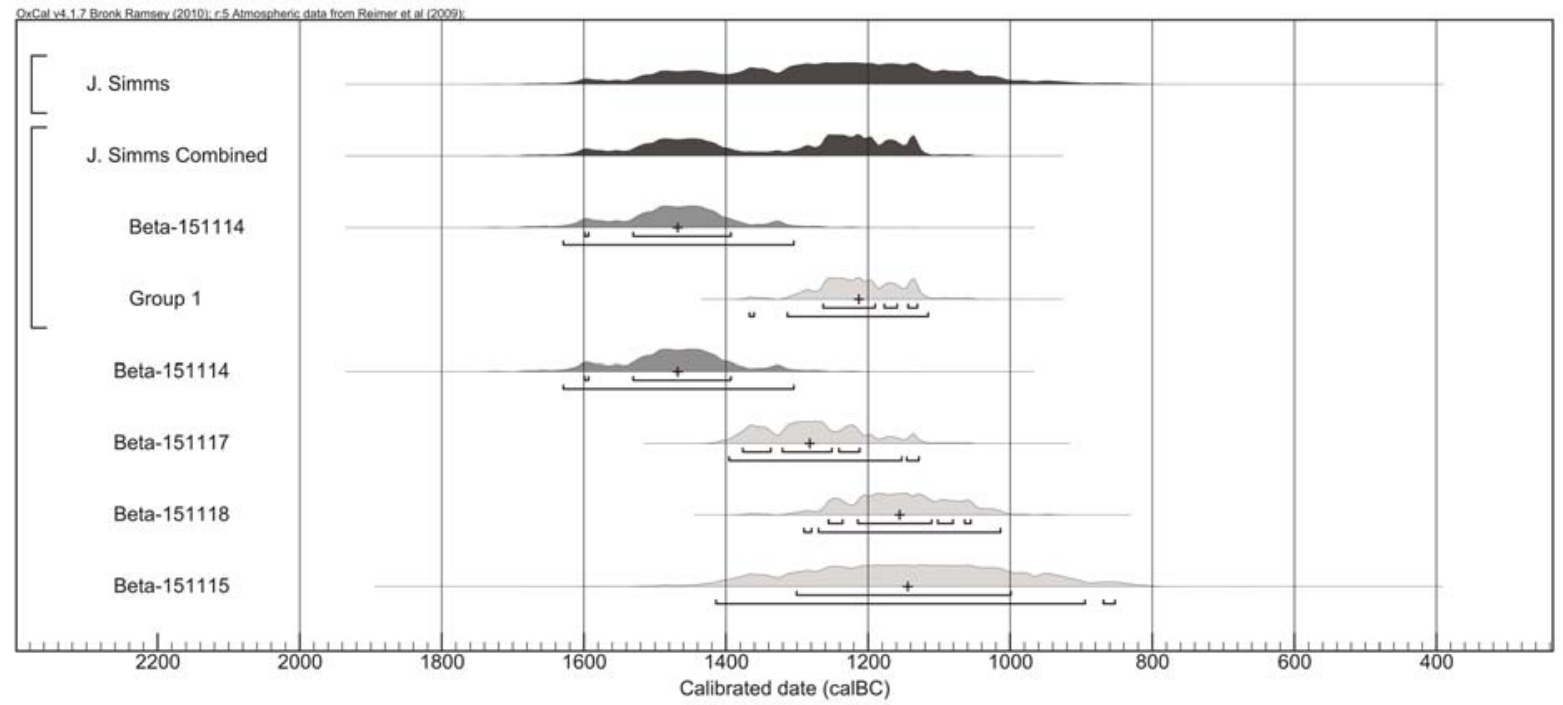

Figure 7. All and combined summed probability distributions for Archaic period dates from the J. Simms site (41NA290) with $1 \sigma$ and $2 \sigma$ ranges, median ages, and number of samples.

\section{Herman Ballew (41RK222)}

Five Archaic period dates from the Herman Ballew site are represented by two individual assays (Beta-72779 and Beta-72780) and one group (Beta-72777, Beta-81715, and Beta-72774) (Figure 8). The conventional age for Group 1 is $2430 \pm 41$ B.P., which has a calibrated $1 \sigma$ age range of 728-693 B.C. (0.13), 658-654 B.C. (0.01), and 542-410 B.C. (0.55), a $2 \sigma$ age range of 753-685 B.C. (0.20), 668-632 B.C. (0.08), 626-611 B.C. (0.02), and 597-402 B.C. (0.66), with a median age of 527 B.C.

\section{Mockingbird (41TT550)}

Four Archaic period dates from the Mockingbird site (Beta-70992, Beta-71230, Beta-70991 and Beta70990) were combined into one group (Figure 9). The conventional age for Group 1 is $2550 \pm 32$ B.P., which has a calibrated $1 \sigma$ age range of 797-752 B.C. (0.43), 686-667 B.C. (0.15), 633-625 B.C. (0.03), and 612-596 B.C. (0.08), a $2 \sigma$ age range of 802-737 B.C. (0.47), 691-662 B.C. (0.17), and 649-547 B.C. (0.32), with a median age of 687 B.C.

\section{UR77}

The Archaic period radiocarbon dates from 41UR77 are represented by six individual assays (Beta166912, UGA-12975, UGA-12979, UGA-12977, UGA-12973 and UGA-12974) and three groups (Figure 10). The conventional age for Group 1 (UGA-12976, UGA-12978, and Beta-166911) is $4182 \pm 31$ B.P., which has a calibrated $1 \sigma$ age range of 2880-2857 B.C. (0.14), 2811-2748 B.C. (0.40), and 2724-2699 B.C. (0.14); a $2 \sigma$ age range of 2888-2835 B.C. (0.22) and 2817-2667 B.C. (0.73); with a median age of 2774 B.C. The conventional age for Group 2 (UGA-12981, UGA-12982, and UGA-12980) is $3160 \pm 24$ B.P., which has a calibrated $1 \sigma$ age range of 1488-1484 B.C. (0.04) and 1454-1412 B.C. (0.65), a $2 \sigma$ age range of 1496-1401 B.C. (0.95), and a median age of 1437 B.C. The conventional age for Group 3 (UGA-12972 


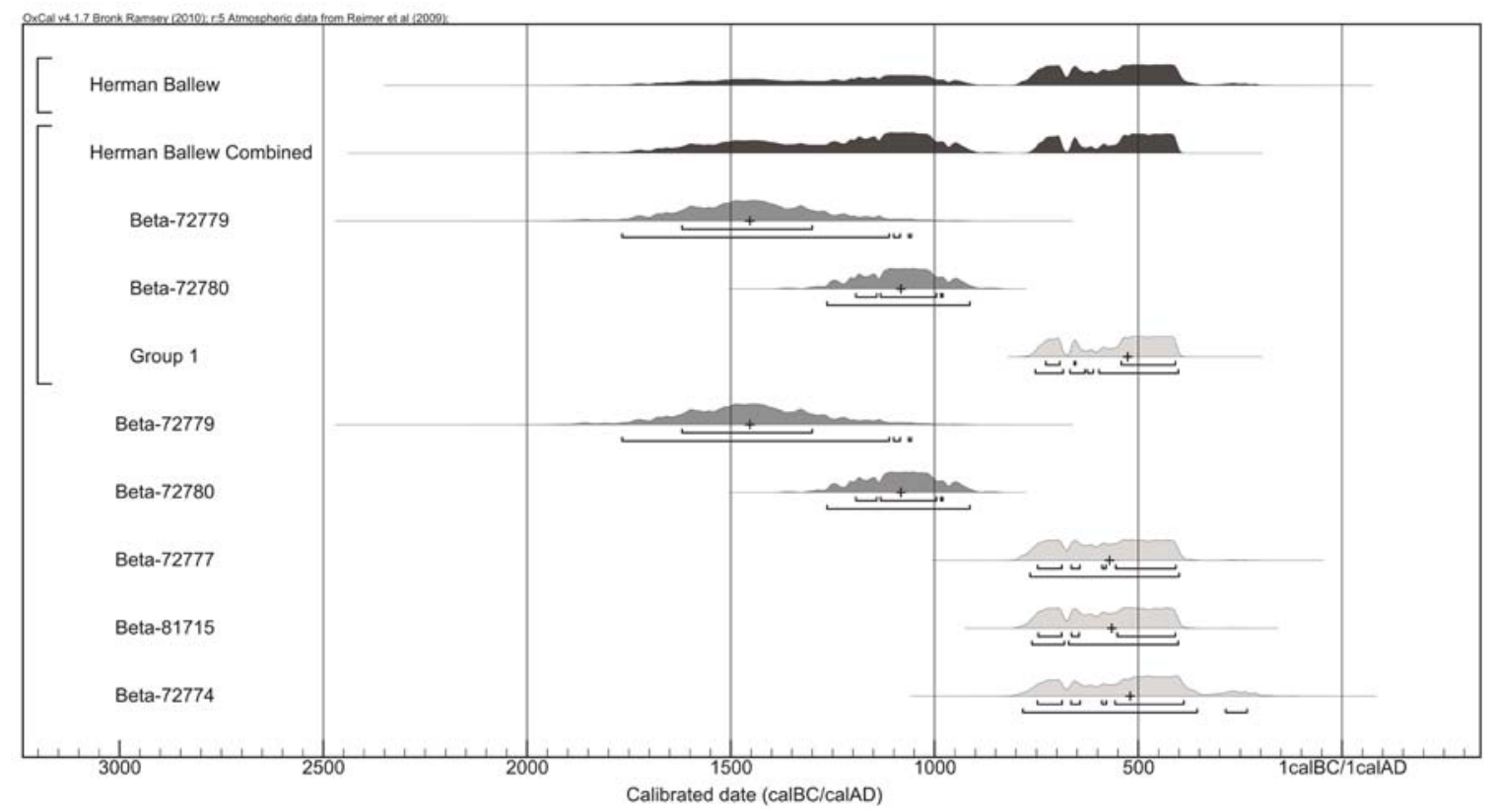

Figure 8. All and combined summed probability distributions for Archaic period dates from the Herman Ballew site (41RK222) with $1 \sigma$ and $2 \sigma$ ranges, median ages, and number of samples.

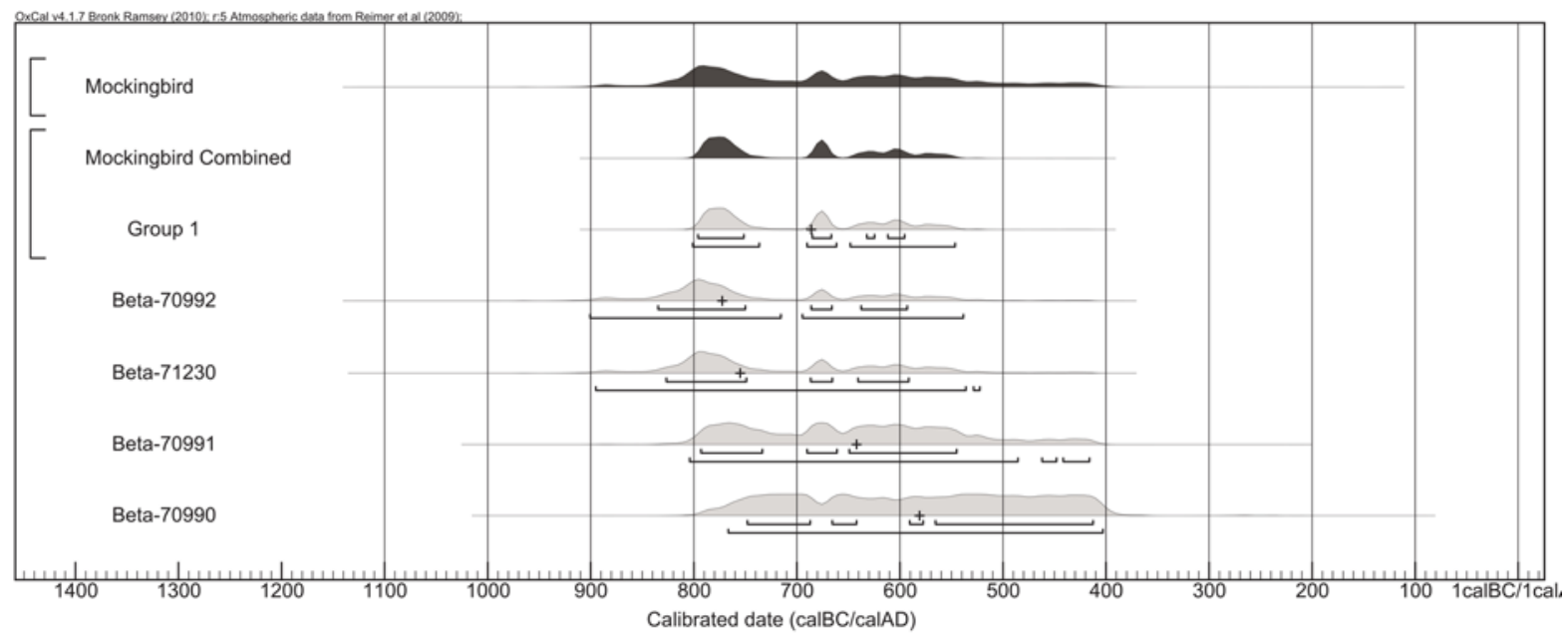

Figure 9. All and combined summed probability distributions for Archaic period dates from the Mockingbird site (41TT550) with $1 \sigma$ and $2 \sigma$ ranges, median ages, and number of samples.

and UGA-12985) is $2905 \pm 29$ B.P., which has a calibrated $1 \sigma$ age range of 1129-1024 B.C. (0.68), a $2 \sigma$ age range of 1211-1006 B.C. (0.95), and a median age of 1094 B.C.

\section{RESULTS}

In every case where date combination was applied, the new combined age replaced the assays used to calculate it. Upon completion of the date combination process, the summed probability distributions for all East Texas sites with Archaic-era radiocarbon assays were plotted chronologically (Figure 11). This allows us - for the first time - to view all of the Archaic-era assays at the regional scale.

In the future, it would be useful to apply some manner of chronometric hygiene (e.g. Reith et al. 2011; Wilmshurst 2011) to the Archaic radiocarbon samples, whether following a conventional method or by vetting 


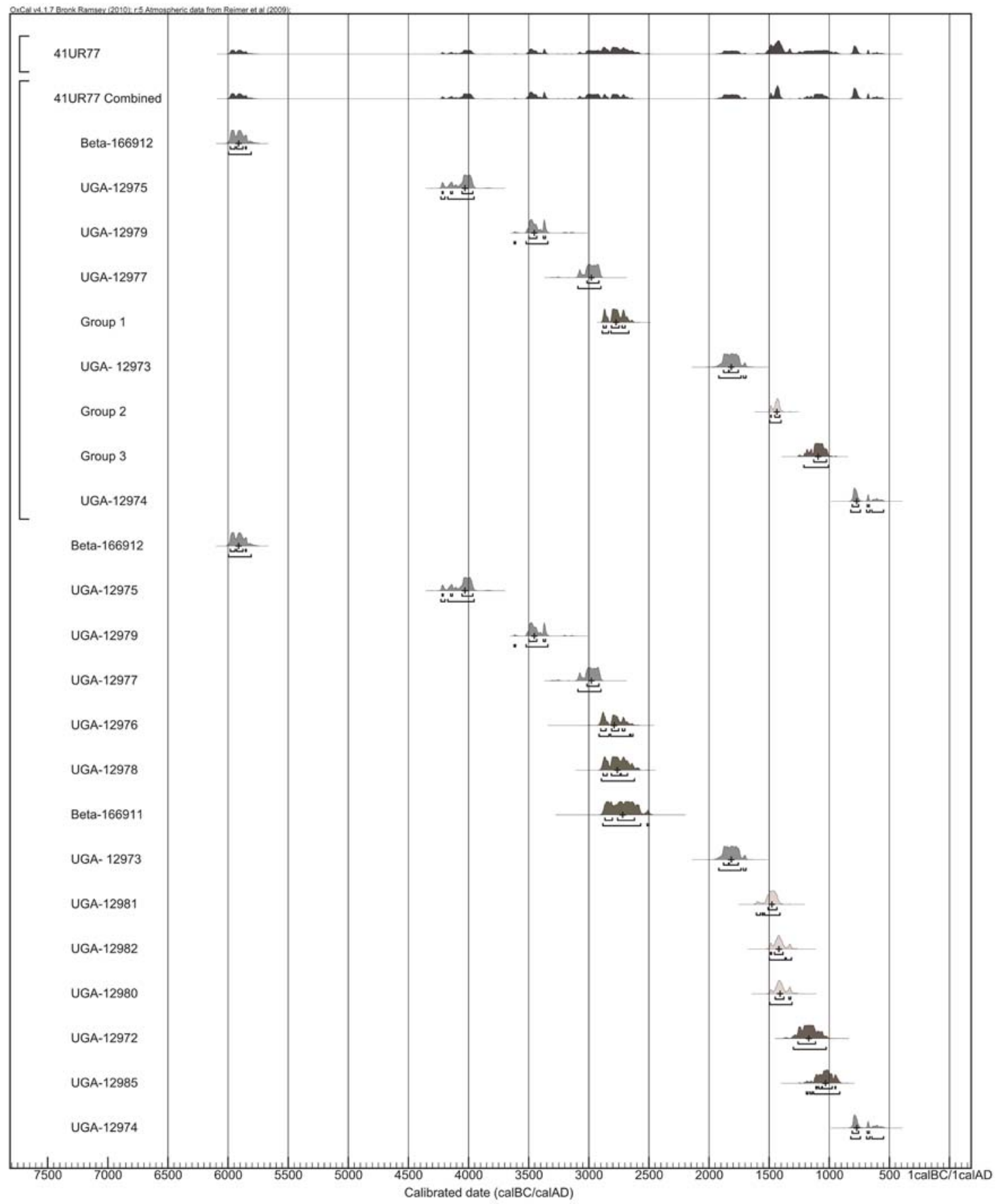

Figure 10. All and combined summed probability distributions for Archaic period dates from 41UR77 with $1 \sigma$ and $2 \sigma$ ranges, median ages, and number of samples.

each date to ensure that the assays represent an Archaic component associated with some manner of human occupation (i.e., artifact manufacture or feature use). At this point it is unknown how many of these dates can actually be attributed to the Archaic occupation of the East Texas landscape, but this preliminary analysis does illustrate a fairly remarkable increase in the number of dates during the Late Archaic (ca. 3000-500 B.C.) period following a sparse dated record for the Early and Middle Archaic. The fact that the number of assays from each period increase through time is a familiar trend (Selden 2012, 2013; Selden and Perttula 2013; Surovell and Brantingham 2007; Surovell et al. 2009), and one that is often attributed to an increase in population size (see Peros et al. 2010). 


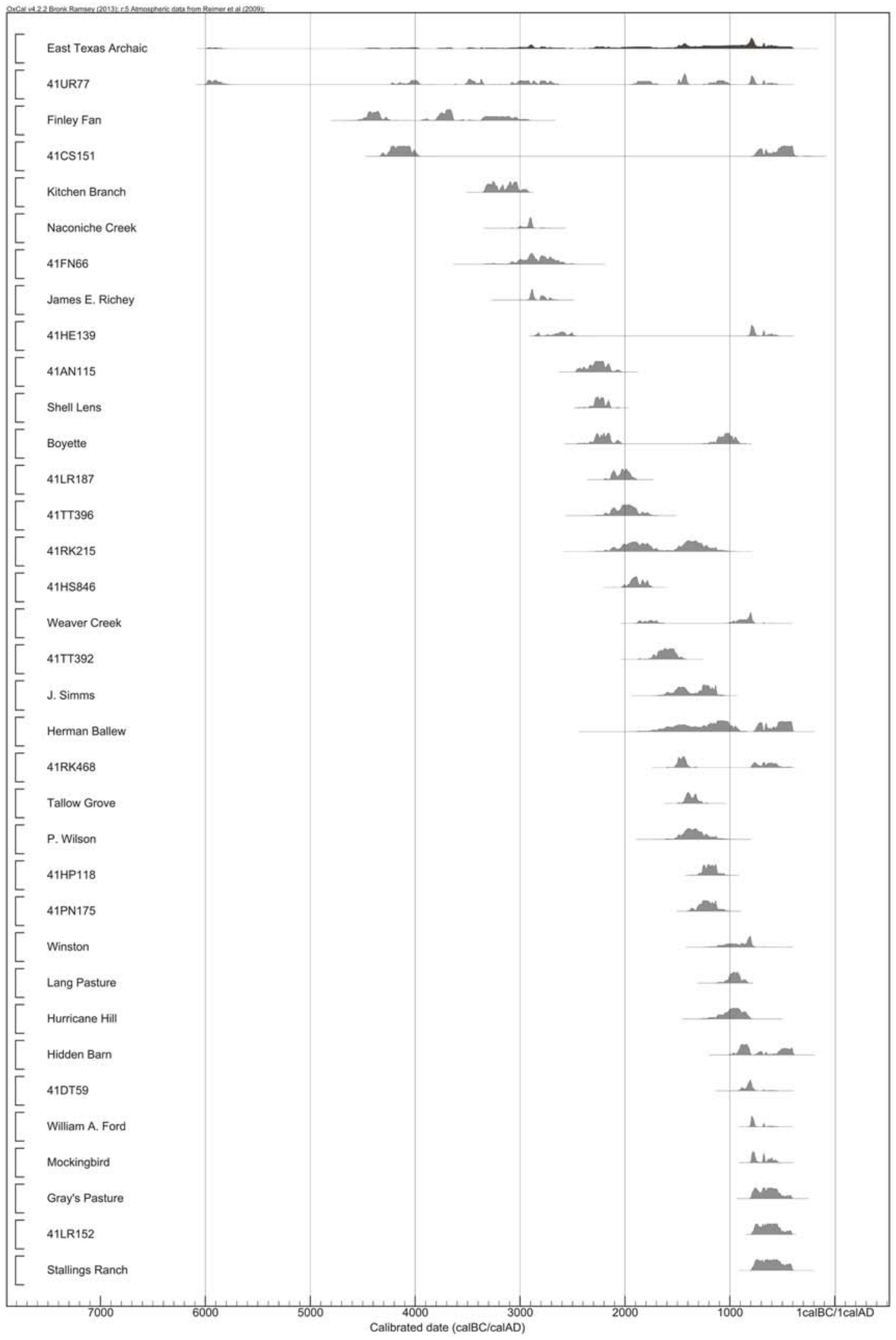

Figure 11. East Texas sites with Archaic-era assays in chronological order. 


\section{CONCLUSIONS}

Although biases likely exist in the radiocarbon sample from sites in the region, it is evident that the most extensive Archaic occupation of East Texas occurred during the Late Archaic period. Certainly more dates are needed from Early and Middle Archaic horizons that may exist at sites, but given the often ill-formed stratigraphy in archaeological deposits that occurs throughout East Texas, finding suitable samples can be a challenge. Also, some measure of chronometric hygiene needs to be applied to this sample of dates to increase their resolution and temporal accuracy. While large steps have been taken to explore East Texas archaeology, the Archaic period remains ill-defined with respect to its material culture as well as our understanding of the chronology. The fact that only 73 dates from the East Texas Radiocarbon Database - which is currently composed of 1248 radiocarbon dates from East Texas - speaks to the need for further research.

\section{REFERENCES CITED}

Bronk Ramsey, C.

2008 Radiocarbon Dating: Revolutions in Understanding. Archaeometry 50(2):249-275.

2013 OxCal 4.1.7.Electronic resource, https://c14.arch.ox.ac.uk/login/login.php?Location=/oxcal/OxCal. html, accessed July 1, 2013.

Clark, R. M.

1975 A Calibration Curve for Radiocarbon Dates. Antiquity 49(196):251-266.

Peros, M. C., S. E. Munoz, K. Gajewski, and A. E. Viau

2010 Prehistoric Demography of North America Inferred from Radiocarbon Data. Journal of Archaeological Science 37:656-664.

Perttula T. K. and R. Z. Selden, Jr.

2011 East Texas Radiocarbon Database. Electronic resource, http://counciloftexasarcheologists.org/?page_ $\mathrm{id}=27$, accessed July 1, 2013

Perttula, T. K. and W. L. Young

2012 Trends in Archaic and Woodland Period Use of the Middle Sabine River Basin Based on Dart Point Proportions. Journal of Northeast Texas Archaeology 37:23-30.

Reimer, P. J., M. G. L. Baillie, E. Bard, A. Bayliss, J. W. Beck, P. G. Blackwell, C. Bronk Ramsey, C. E.

Buck, G. S. Burr, R. L. Edwards, M. Friedrich, P. M. Grootes, T. P. Guilderson, I. Hajdas, T. J. Heaton, A.

G. Hogg, K. A. Hughen, K. F. Kaiser, B. Kromer, F. G. McCormac, S. W. Manning, R. W. Reimer, D. A.

Richards, J. R. Southon, S. Talamo, C. S. M. Turney, J. van der Plicht, and C. E.Weyhenmeyer

2009 IntCal09 and Marine09 radiocarbon age calibration curves, 0-50,000 years cal BP. Radiocarbon 51(4):1111-1150.

Reith, T. M., T. L. Hunt, C. Lipo, and J. M. Wilmshurst

2011 The 13th Century Polynesian Colonization of Hawai'I Island. Journal of Archaeological Science 38:2740-2749.

Selden Jr., R. Z.

2012 Modeling Regional Radiocarbon Trends: A Case Study from the East Texas Woodland Period. Radiocarbon 54(2):1-27.

2013 Consilience: Radiocarbon, Instrumental Neutron Activation Analysis and Litigation in the Ancestral Caddo Region. Ph.D. dissertation, Department of Anthropology, Texas A\&M University, College Station.

Selden Jr., R. Z. and T. K. Perttula

2013 Radiocarbon Trends and the East Texas Caddo Tradition (ca. A.D. 800-1680). Southeastern Archaeology 32(1):85-96. 
Stuiver, M. and P. J. Reimer

1993 CALIB User's Guide Rev 3.0.3A for Macintosh computers. Quaternary Research Center, University of Washington, Seattle.

Surovell, T. A. and P. J. Brantingham

2007 A Note on the Use of Temporal Frequency Distributions in Studies of Prehistoric Demography. Journal of Archaeological Science 34:1868-1877.

Surovell, T. A., J. B. Finley, G. M. Smith, P. J. Brantingham, and R. Kelly

2009 Correcting Temporal Frequency Distributions for Taphonomic Bias. Journal of Archaeological Science 36:1715-1724.

Ward, G. K. and S. R. Wilson

1978 Procedures for Comparing and Combining Radiocarbon Age Determinations: A Critique. Archaeometry 20(1):19-31.

Wilmshurst, J. M., T. L. Hunt, C. P. Lipo, and A. J. Anderson

2011 High-Precision Radiocarbon Dating Shows Recent and Rapid Initial Human Colonization of East Polynesia. Proceedings of the National Academy of Sciences 108(5):1815-1820. 